\title{
The Opera House of the West CAMERON MUIR
}

I turn off the Mitchell Highway outside the New South Wales town of Wellington and drive east into undulating pastoral lands. From here it is about 30 kilometres to the Burrendong Dam, an earth-filled structure across the Macquarie River that was once dubbed 'The Opera House of the West'. It is difficult to associate this lonely rural valley with a bustling quay and a building that gleams with over a million white and cream tiles. On a treeless rise I can see a brick farmhouse but there is no movement, not even a car parked in its pale gravel driveway. There are no fellow travellers on this narrow road. After winter rain the grass is not high, but it is green, and afternoon sun catches the ridges of low north-south running hills, creating parallel lines of gold and shade across the slopes.

Between 1958 and 1965 a team of up to 1000 workers at a time cut a 1.1 kilometre scar into this alluvial valley floor. With heavy earthmoving equipment they moved 1.3 million cubic metres of rock and dirt to strip the ground to bedrock. The rock buggies' giant tyres lasted a month before they were worn bare. Workers quarried a further 1.4 million cubic metres of river gravel from an ancient stream bed, and heaped this with more locally excavated material to form a 6.3 million cubic metre pile of rocks, clay and gravel. That is around 50,000 B-Double road trains worth of material, which, parked from end to end, would reach from Sydney to Adelaide. What is the relationship between this dull pile of rocks in the back blocks of New South Wales and the architectural icon of a vibrant harbour city?

Both were nation-building projects conceived in the post war boom. They were under construction at the same time and were plagued by chequered and controversial beginnings. After two decades of slow and interrupted construction, a major design revision, and a rise in costs from an initial estimate of $£ 2$ million to final costs heading towards a decimal \$40 million, the Burrendong Dam earned the tag 'The Opera House of the West'. It became a running joke along the river 'from Bathurst to Brewarrina', as well as in metropolitan newspapers and state parliament (A. Goodall 2). In 1962 the Minister for Conservation assured New South Wales Parliament that the Burrendong Dam wall would be completed within the next two years, eighteen years after work had begun. In response, the Country Party's William Chaffey quipped, 'It's a pity that the Government did not put the Minister for Conservation in charge of the Opera House' (New South Wales Vol. 42: 1060). 
Leaving the ironic humour behind, it is still a useful pairing. The Opera House was cast as belonging to the world of aesthetics and taste, as an indulgence for those interested in the arts. Conservative political parties labelled it an 'extravagance' for Sydneysiders (Bartizan). Publicly funded dams, in contrast, were presented as practical and necessary. Geoffrey Crawford, a Country Party member who joined the Askin ministry, argued it was a 'tragedy' that millions were being spent on the Opera House 'when money is withheld for the building of water conservation schemes' (New South Wales Vol. 41: 665). We rarely think of dams as part of our cultural heritage, and are more likely to take them for granted as belonging to a separate utilitarian category of 'resource management'. This perception is founded on a modern dualism that separates culture from nature and it partly explains why we turn to technical and scientific solutions that are part of the problem that we are trying to solve (Weir). Environmental degradation of our hydrological systems, rivers in particular, has not been a result of a lack of knowledge or ignorance, or a failure of science. Scientific knowledge helped engineer large dams within a framework of conservation that pitted production against environment. As historian Tom Griffiths has observed, problems that had been defined as 'purely scientific or material' are beginning to be recognised as 'fundamentally social' (Griffiths, 'The Humanities'). We need a method of critique in addition to, or in conversation with scientific inquiry; one that is good at synthesis, and which reaches an audience beyond that of a bureaucrat's report.

This is what creative non-fiction, and the humanities generally, are good at. I take a creative non-fiction approach in parts of this essay to help argue the case for why narrative is important for environmental understanding. Few people would say the roughly quarried grey rocks that form the Burrendong Dam embody the heights of imagination. Nevertheless, in continuing this tour, acting as both tourist and tour guide, I will explore further the ways in which the dam can be seen, just like the Opera House, as a product of ideological and cultural desires. The story I want to tell is a story of the dam and the river that tries to get beyond so many megalitres; beyond abstract resource management language that makes the rural appear utilitarian rather than cultural and ideological. I argue that cultural desires and values have played a large role in determining how we perceive 'problems' and the solutions they require throughout the changing ideological projects of empire, nation and economy. In this narrative tour of the dam site I will try to build a picture of the material consequences of cultural understandings and interactions with place. This work of imagining and analysis is shared, to some extent, between author and reader. I end with reflections on the importance and possibilities of the humanities in environmental research. 
I turn off onto the access road to the spillway which is 3 kilometres from the dam wall. From this plateau above the lake there is a good view of the seven radial gates and energy dissipater. The purpose of the spillway is to dampen occasional high inflows from the highlands. It was added to the design after a large flood in 1955. Flooding, drying, and changing course is an integral part of the river's activity. The Macquarie does not have well-defined channels; Wiradjuri people call it the Wambool, which means meandering or wandering. Before the dam was built, the Macquarie had the highest variability ratio of the major rivers in the Darling system. The range between the river's highest and lowest flows was from 2 percent to 940 percent of the average annual flow (Murray-Darling Basin Ministerial Council 79). The average for the rest of the world's rivers, such as the Amazon and Yangtze, is 2 to 3 times (Craik). This exasperated the early surveyors. Oxley lauded the Macquarie when he followed it in winter 1817. In a letter to the Governor he described it as 'a noble river of the first magnitude', broader and deeper than the Hawkesbury and Nepean rivers (Oxley). A decade later Hume arrived at the same camp along the river, but in summer; he wrote, 'the Macquarie River here ... can be crossed without wetting your foot, so much, for Mr Oxley's River of the first Magnitude' (Hume 11).

People living on the river felt that having to rely on those variable rhythms was uncivilised. When the construction of Burrendong Dam was postponed in 1952, town leaders were incensed. At a public meeting held in Dubbo, an Alderman put his case for why the Macquarie should be regulated. He referred to a drought twelve years earlier when, as he says, "The Macquarie River, that fine stream you saw today, was then nothing but a series of dirty stinking water holes that municipalities had to pump from to get their water supplies from day to day' ('Urgent Need' 3). The waterholes played an important role in the biotic life of the river, and as the Alderman's statement reveals, they were important sources of water that could be relied upon in dry times. He spoke of the river with distaste. It did not flow in ways that conformed to his European sensibilities of what a river should be.

Relationships with environment had long been at the heart of concerns about progress and civilisation in Australia. White people in the antipodes 'were haunted by the spectre of degeneration' (Griffiths, 'Social and Intellectual' 16). Towards the end of the nineteenth century politicians such as Andrew Garran explained to the colonising population, and to a wider audience in the old world, that Aboriginal people had been 'kept down' because of 'capricious' climatic conditions (Garran iii). The key to maintaining civilisation was to 'neutralize the precariousness' of the Australian environment (Garran iii). Cultivation and its requirement for sedentary land occupation and close settlements was the key to 
safeguarding and advancing civilisation. The material entanglements between this discourse and the riverine plains have marked the history of environmental change and social relations along the Macquarie.

It was this ideology that underpinned the dispossession of Wiradjuri and Wailwan people of the Macquarie River. The Macquarie Marshes are an important place for the Wailwan, Wiradjuri, Kamilaroi, and other neighbouring people, and large bora ceremonies were frequently held on the black clay soils. The Wailwan people of the Marshes worked in the pastoral industry and incorporated stock work into their dances (Miller and Donaldson). In 1935 the New South Wales Government forcibly moved the people from the Marshes area to Brewarrina. Heather Goodall provides the context for this in the 'Dog Act' chapter of Invasion to Embassy. Economic depression, the entry of scientific discourse into bureaucratic management, white demands for land and segregation, and increasing encroachment of agriculture into pastoral lands, contributed to circumstances in which the Aboriginal Protection Board could carry out its aims of concentrating Aboriginal people into camps with prisonlike conditions (H. Goodall). Pastoralists and agriculturalists alike benefitted from the dispossession of Aboriginal people. By the time the Burrendong Dam was nearing completion in the 1960s, pastoralists voicing their concerns about the impact the dam would have on their flooded country and grazing operations were dismissed within a similar discourse about civilisation and relationships with land.

The Macquarie Marshes are a verdant network of braided channels and lagoons that spreads across the plains before the Macquarie reaches the Barwon-Darling. Although the vast wetland supports diverse life it has not been suitable as land for agriculture. Any primary production that relied on variable water flows was also regarded as uncivilised in a modern society with an ideological commitment to rationalised industrial agriculture. For half a century pastoralists on the Macquarie Marshes had argued against the construction of the Burrendong Dam because they relied on regular small floods over their properties. The Marshes were once prime grazing land. Famous studs such as Haddon Rig, Raby and Egelabra gained world record prices for their stock. Conversely, irrigation supporters cast the Marshes as wild and 'unimproved', and the farming methods there as 'rough and ready' and 'haphazard' ('No Surprises' 3), in contrast to 'the skilful and experienced large scale irrigators [...] who make scientific use' of water ('Is Burrendong' 1). The pastoral landholders who lived and worked with periodic flooding and drying were as backward and inadequate as the marsh environment.

Local irrigation lobby groups started producing notices in the newspaper that predicted and outlined planned uses for the newly available water. They divided up the potential capacity, not calculating how much water would be in the dam 
in different years. They saw a new resource, produced through engineeringwater abstracted from complex river ecosystems. They drew miles of channels for the phantom megalitres with little thought to the dry and variable past. They ploughed their machinery through the brown, red and black soil plains, free from uncertainty. They ploughed their way into the future, the past trailing away, curling up behind them like wisps of dust. In addition to the dam's physical effects on the river, it also legitimises high expectations for water extraction and associated industries. It produces a perception that production of a limited range of commodities is the river's purpose.

The Water Conservation and Irrigation Commission (WCIC) studied river gauge records and knew that the beneficial flooding that the Macquarie Marshes received would be reduced with regulation of the river. This was an acceptable consequence to ensure a more civilised culture of land relations and primary production. Landholders, ecologists and members of the public with an interest in the Marshes cautioned that the reed beds would shrink and that there would be heavy losses to the large bird numbers and breeding grounds that the Marshes are internationally recognised for. In 1962 The Sydney Morning Herald published a letter that warned 'these marshes are now threatened with extinction', as construction of the dam continued (Cuthbert). The letter outlined the likely economic, cultural, aesthetic and ecological consequences of river regulation. Four days later the Secretary for the WCIC responded in The Sydney Morning Herald with assurances, contrary to the Commission's own reports, that the dam would be no threat to the Marshes or its wildlife. He stated that the Commission was investigating the best ways to "maintain the marshes at a desirable level and utilise to the best advantage the water to be allocated to them annually' (Quilty). Ten years later the author of the first letter would have had the opportunity to see what the WCIC meant by 'desirable level' and 'best advantage'. The WCIC excavated a channel and built embankments to divert water away from the northern reed beds so that the water could be used for a planned irrigation scheme past the Marshes. Despite opposition the works were approved and were justified as a completion of the Burrendong Dam project (Johnson 71).

The changes in the Marshes, from the introduction of stock to the development of industrial agriculture, are complex, multiple, and wide-ranging. Since authorities started regulating the Macquarie, the river has changed the work it does on the floodplains. It used to spread easily across the plains, depositing rich nutrients. Now with constant low flows the river erodes channels in the Marshes so that currently three times as much water is needed to fill the stream beds over their banks to allow water to spread (NSW Department of Natural Resources). Richard Kingsford led research that showed the flooded area had reduced by up to $50 \%$ by 1993 and waterbirds were in decline (Kingsford and 
Thomas). Bureaucrats, scientists and landholders knew the dam would damage river health but went ahead anyway. We like to excuse the past by saying people did the best they could with the knowledge they had, and make ourselves more comfortable about what we are doing by saying we know much more, that we are better now. As the activities of the people on the river plains show, it was cultural attitudes, not ignorance, that shaped how problems were constructed and what solutions were demanded and provided by science.

I drive the 3 kilometres back to the dam wall, and pull up on a two lane road on top the wall itself. I am between the old and the new regime. On one side is the rocky basin of the lake, marked with the consecutive rings of varying water levels, on the other side is a small stream dribbling from the base of the wall and running though a green valley. Local papers predicted Burrendong Dam would be 'an undoubted tourist resort' ('Burrendong Now' 1). In preparation trees were cleared from the foreshores to allow for water sports ('National Parks' 2). To control rabbits and prevent erosion around 200 tonnes of carrots laced with 1080 poison were dropped by air over the 'tourist resort' ('Rabbit Poison' 8).

From this position on top of the wall I can see a swimming area overgrown with yellow grass, and from the end of the old concrete boat ramp a dirt road runs across a desolate basin to the water's edge. No one is around, so I decide to climb down the rocks of the wall to the outlet works car park and picnic area. I make it to the base of the 76 metre high wall. From here it dominates the gully and denies views to the body of water that it impounds. Before Burrendong Dam was completed the WCIC conducted daily tours of the site and in less than two years 33,500 people had visited it ('Burrendong Now' 1). With no views and no opportunities for swimming, fishing or boating, the outlet works picnic area was established to bring visitors to see the dam wall as a monument. It is a place to be awed by the grandeur and promised security of such an engineering feat; it is a place to take comfort in the human power to bring order to nature on a grand scale. As I take a stroll around this playground in the shadow of the wall, it is hard not to see the amenities as decaying remnants of past optimism, a museum of rural decay and stubbornness, of failed big ideas. We have to listen hard for the echo of lost tourists.

These two modernist projects, the Sydney Opera House and Burrendong Dam, show a society at unease with its constructed separation of humans from the rest of nature. The Opera House is an example of organic architecture, a movement that attempted to create buildings that drew form from natural features, and to create buildings in aesthetic harmony with their natural surroundings and environment. They yearned for a return to an idealised nature. The dam, on the other hand, is against nature. It stands out from its surrounds. Its creators 
rejected the variable rhythms of the river, and tried to order and control what they saw as an external and unworthy nature. They sought to turn the river into an irrigation channel, a delivery method for units of water.

I leave the picnic area and walk to the edge of the outlet works. The main component of the works is a small cement structure at ground level that looks similar to the discharge pipes of urban storm water drains. These pipes release cold water from the bottom of the dam into the Macquarie River. This is thermal pollution and it is a major cause of degradation of river ecosystems in regulated rivers around the world. Water in dams stratifies into layers that are warm at the top and very cold at the bottom. Water released from the bottom layer is dense, up to $12^{\circ} \mathrm{C}$ colder than river water in natural summer conditions, and contains little saturated oxygen. This disrupts the breeding patterns of native fish and other aquatic creatures. It destroys life at the very bottom of the food chain. The shock of a sudden temperature drop and low oxygen can be enough to kill native fish outright. In an experiment conducted just below Burrendong, researchers from NSW Fisheries monitored the response of juvenile Silver Perch (Bidyanus bidyanus) to the dam's cold water. Nineteen out of the 20 Silver Perch in natural water temperatures survived, while only 5 out of the 20 fish survived in the water from the bottom of the dam. They found that the effects of cold water pollution extended 300 kilometres downstream from the Burrendong Dam outlet works (Astles et al.).

The Fisheries report is a striking illustration of how the effects of the dam are total and ongoing. Yet this report has received little public attention. It is not even well known or referenced in government led community plans for the Macquarie River - there is no fishing industry on the Macquarie, so there are no 'stakeholders' on this issue. Why hasn't the knowledge produced in the report generated action? Effects of thermal pollution were known at the time the dam was built, and are well understood now, yet large dams are still being constructed that have not used designs that minimise thermal pollution. Some existing dams in Australia, such as Glenbawn on the Hunter, are slowly being modified to reduce thermal pollution, but it is not a priority, and there is little funding. We seem to be content thoroughly to document the degradation and decline of ecological systems, but put fewer resources into trying to understand our values, perceptions and relationships with nature. We rarely put the same effort into fostering robust and healthy ecological systems and mutually beneficial relationships.

Simply identifying degradation and the way a system functions is not enough. We have to interrogate our values, ask why we act or fail to act, what our priorities are and how we form them. The humanities provide techniques for connecting large and diverse data, for critiquing the production of knowledge, and for focusing on problem-framing rather than problem-solving (Robin and 
Connell). One of its most powerful tools for doing this is narrative. Cultural and environmental historian Tom Griffiths argues passionately for the role of story: 'I would argue that narrative is not just a means, it is a method, and a rigorous and demanding one. The conventional scientific method separates causes from one another, it isolates each one and tests them individually in turn. Narrative, by contrast, carries multiple causes along together, it enacts connectivity. We need both methods' (Griffiths, 'The Humanities'). Creative non-fiction makes use of narrative to appeal to the hearts and minds of wider audiences. It engages readers with the ordinary and particular, and provides different perspectives. We need to care for places we do not necessarily have or feel any connection to.

Economist R. Quentin Grafton and environmental historian Libby Robin remind us in the introduction to Understanding the Environment that 'Ideas about how to act on knowledge must be delivered to audiences beyond any one discipline,' because environment affects everyone, every species; and that, 'Accessible, good quality writing is generally far more influential than work published in prestigious journals' (Grafton, Robin and Wasson 3). They provide the example of Rachel Carson's Silent Spring, which brought world-wide attention to the effects of pesticides, but Australia has its own long history with writers from science and the humanities who have ventured beyond the language and ideas of their disciplines to write creative and engaging stories about Australia and our place in the environment.

One of the first was Sir Francis Ratcliffe, who in 1938 published Flying Fox and Drifting Sand: The Adventures of a Biologist in Australia, which, as the title suggests, is a travel/adventure story, with a stark warning about the permanent destruction of native vegetation due to overgrazing, and the widespread erosion that followed. George Seddon, Judith Wright, the late Eric Rolls, and Tim Flannery are among a host of authors who have written popular work that has played a significant role in shaping Australian environmental consciousness. In my view creative non-fiction is a form well placed to break down conventions and assumptions, engage diverse audiences, and ultimately, assist us with the broader long-term project of re-embedding human culture within more-thanhuman nature.

It is time to bring the tour to an end. At Burrendong the last glow of the sun dwindles in the western horizon. I start my climb back to the car. By the time I reach the top a fog is beginning to form back down in the valley. I turn the engine over and switch on the lights. It is dark at Burrendong and I will leave you with this dark prediction, one that brings the earlier concerns of landholders and townspeople full circle. 
If we continue our current environmental practices the Macquarie River will be so degraded by 2020 that the water at major towns such as Dubbo and Narromine will unfit for human consumption 30\% of the time (Murray-Darling Basin Commission 31). By 2050 the salt load will be so great that biodiversity will be reduced and the river will support few if any agricultural products (National Land and Water Resources Audit; Murray-Darling Basin Commission). After that, the river's resilience to modification will have broken. It'll be a new system, one that does not support anywhere near as much life as before. Once again, we have the knowledge, but will we change our culture to act on it?

Cameron Muir is a PhD student at the Fenner School of Environment and Society, Australian National University. He is writing a history of agricultural and conservation science on the western plains of New South Wales that explores relationships between science and place. He maintains the website of the Australian and New Zealand Environmental History Network and is a member of the Ecological Humanities.

\section{Works Cited}

Astles, K.L., et al. 'Experimental Study of the Effects of Cold Water Pollution on Native Fish.' NSW Fisheries Final Report Series 44. Sydney: NSW Fisheries Office of Conservation, 2003.

Bartizan, Paul. 'Sydney Opera House architect, Jørn Utzon dies'. World Socialist Web Site. 10 December 2008. http://www.wsws.org/articles/2008/dec2008/ utzo-d10.shtml. Accessed 28 September 2009.

'Burrendong Now in Final Stages of Completion.' Narromine News and Trangie Advocate, 15 January 1965: 1.

Craik, Wendy. 'Weather, Climate, Water and Sustainable Development. World Meteorological Day 2005 Address'. Murray Darling Basin Commission, 2005. http://www.mdbc.gov.au/_data/page/55/CE-World-Met-Day-Address.pdf Accessed 28 September 2009.

Cuthbert, A. B. 'Dam's Threat to Wildlife.' Letter to the Editor. Sydney Morning Herald, 24 August 1962: 2.

Garran, Andrew, ed. Australasia Illustrated. Sydney: Picturesque Atlas Publishing Company, 1892.

Goodall, Alan. 'What to Do with All That Dam Water?' Sydney Morning Herald, 4 August 1967: 2. 
Goodall, Heather. Invasion to Embassy: Land in Aboriginal Politics in New South Wales, 1770-1972. 2nd ed. Sydney, N.S.W.: Sydney UP, 2008.

Grafton, R. Quentin, Libby Robin and R. Wasson, eds. Understanding the Environment: Bridging the Disciplinary Divides. Sydney: U of New South Wales P, 2005.

Griffiths, Tom. 'The Humanities and an Environmentally Sustainable Australia.' Australian Humanities Review 43 (2007). http://www. australianhumanitiesreview.org/archive/Issue-December-2007/ EcoHumanities/EcoGriffiths.html Accessed 28 September 2009.

- 'The Social and Intellectual Context of the 1890s.' Exploring Central Australia: Society, the Environment and the 1894 Horn Expedition. Eds. D. J. Mulvaney and S. R. Morton. Chipping Norton, N.S.W: Surrey Beatty \& Sons, 1996. 13-18.

Hume, Hamilton. 'Letter from Hamilton Hume to an Unknown Person, 4 Dec. 1828.' Hamilton Hume - Correspondence, 1810-1867, with associated papers, 1910-1919. Mitchell Library MS (Ah 12/4). http://image.sl.nsw.gov.au/cgibin/ebindshow.pl?doc=ah12/a1260;seq=9 Accessed 28 September 2009.

'Is Burrendong Water to Grow Reeds or Food?' Narromine News and Trangie Advocate, 25 March 1966: 1.

Johnson, William John. 'Adaptive Management of a Complex Social-Ecological System: The Regulated Macquarie River in South-Eastern Australia.' MA Thesis. Armidale: University of New England, 2005.

Kingsford, Richard T. and Rachael F. Thomas. 'The Macquarie Marshes in Arid Australia and Their Waterbirds: A 50-Year History of Decline.' Environmental Management 19.6 (1995): 867-78.

Miller, Steve, and Tamsin Donaldson. Sharing a Wailwan Story: Education Kit. Ultimo, N.S.W.: Powerhouse Museum, 1999.

Murray-Darling Basin Commission. The Salinity Audit of the Murray-Darling Basin: A Hundred Year Perspective. Canberra: Murray-Darling Basin Commission, 1999.

Murray-Darling Basin Ministerial Council. Murray-Darling Basin Environmental Resources Study. Sydney, N.S.W.: State Pollution Control Commission, 1987.

'National Parks for the Central West Envisaged.' Sydney Morning Herald, 27 November 1961: 2. 
National Land and Water Resources Audit. 'Australian Dryland Salinity Assessment 2000: Extent, Impacts, Processes, Monitoring and Management Options.' Canberra: National Land and Water Resources Audit, 2001. http:// www.anra.gov.au/topics/salinity/pubs/national/salinity_contents.html Accessed 28 September 2009.

New South Wales. 'Parliamentary Debates.' Legislative Assembly, 1962. 1-788. Vol. 41.

—. 'Parliamentary Debates.' Legislative Assembly, 1962. 789-1576. Vol. 42.

'No Surprises in Conservation Minister's Decision on Water from Burrendong Dam.' Narromine News and Trangie Advocate, 23 December 1966: 3.

NSW Department of Natural Resources. 'Wetlands: Feature on the Macquarie Marshes'. NSW Department of Natural Resources. http://www.iqqm.com/ water/wetlands_area_mvalley_feature.shtml\#Erosion Accessed 5 April 2008. Link no longer active.

Oxley, John. 'Letter from Oxley to Governor Advising of His Return from First Expedition. 30 August 30 1817.' Journals of Two Expeditions into the Interior of New South Wales. (1817-18). http://ebooks.adelaide.edu.au/o/oxley/john/ o95j/appendixl.html Accessed 28 September 2009.

Quilty, A. J. 'Wildlife Not in Danger.' Letter to the Editor. Sydney Morning Herald, 28 August 1962: 2.

‘Rabbit Poison No Risk-Official.' Sydney Morning Herald, 7 February 1967: 8.

Robin, Libby, and Daniel Connell. 'History and the Environment.' Understanding the Environment: Bridging the Disciplinary Divides. Eds. R. Quentin Grafton, Libby Robin and R. Wasson. Sydney: U of New South Wales P, 2005. 8-22.

'Urgent Need for Burrendong Dam Stressed by Western Speakers: “Amenities for Country as Well as City".' Narromine News and Trangie Advocate, 12 December 1952: 3.

Weir, Jessica Kate. Murray River Country: An Ecological Dialogue with Traditional Owners. PhD Thesis. Canberra: Australian National University, 2007. 